\title{
Sachi Prasad Ray-Chaudhuri
}

\section{September 1907-15 February 1994}

Professor Sachi Prasad Ray-Chaudhuri, the pioneer of Dro-sophila genetics and animal cytogenetics in India, passed away on 15 February, 1994, at his residence in Calcutta. He was 86. With his demise we have lost a teacher, a scientist, and a crusader. While writing a foreword to the book "Trends in Chromosome Research", which was published in 1990 as a dedication to Ray-Chaudhuri, T.C. Hsu most succinctly described him as a "scholastic builder". RayChaudhuri embarked upon his pursuit at a time when genetics was not in the central theme of biological science.

Having received his M.Sc. in Zoology from Calcutta University in 1931, Ray-Chaudhuri's desire to improve strains of silk worm in India took him to the Institute of Animal Genetics, Edinburgh, where his fortuitous association with H.J. Mull-er altered the course of his career. He worked on the effects of extreme low intensity radiation on the mutation frequency in Drosophila, to show for the first time that the damage caused was proportionate to the dose irrespective of its intensity. Before returning to India in 1941, he also learned chromosome methodologies from P.C. Koller. Thus, even though Ray-Chaudhuri did not work on silk worms, his knowledge stood him in good stead for the job of establishing genetics teaching and research in India. But in the India of the 1940s there was hardly any awareness of the science of genetics, especially animal genetics. Undeterred, Ray-Chaudhuri initiated work on radiation-induced chromosome aberrations in meiosis, using the grasshopper as a model system. He also studied karyotypic evolution in various groups of insects. Later, J.B.S. Haldane, adjudicator of Ray-Chaudhuri's doctoral dissertation, used his good offices to help Ray-Chaudhuri set up a Drosophila-laboratory at Calcutta University where, besides research, theoretical and practical training in genetics was initiated as part of the M.Sc. teaching curriculum in 1955-56. That was the first Dro-sophilalaboratory in India; now there are nearly a dozen very competent ones. But the real opportunity for Ray-Chaudhuri to accomplish the task of bringing animal genetics to the forefront of science in India arose when he took up the chair of the Department of Zoology at Banaras Hindu University in 1960. Studies on radiation and population genetics of Drosophila were pursued vigorously. A tissue culture laboratory, which he set up in 1963 to study human cytogenetics, helped him to div-

(C) 1994 S. Karger AG, Basel

ersify to other vertebrates as well. His contributions in evolutionary cytogenetics, especially with respect to the differentiation of sex chromosomes in vertebrates, started during this period. The later discoveries of sex-specific DNA sequences in snakes and other groups had their genesis in his work on the mechanism of sex chromosome differentiation in snakes.

Ray-Chaudhuri made a conscious effort to diversify his research into various areas of genetics and cytogenetics. Thus, his contribution lies not merely in the papers he published but in his endeavor to equip a whole generation of students with a comprehensive perspective on the subject. It was due to his persuasive effort that genetics became an integral part of biology curricula in Indian universities. During his tenure as Zoology chairman at Banaras Hindu 
University (1960-71), Ray-Chaudhuri created an ambience where not only genetics but also other emerging areas of animal science were initiated and nurtured for teaching and research. Ray-Chaudhuri led a long life and, except for the last few years when he was confined to bed, it was a life of exemplary determination. He retired from Banaras Hindu University in 1971 but continued to work in Calcutta until recently. His last

$\mathrm{Ph} . \mathrm{D}$. student graduated when Ray-Chaudhuri was nearly eighty. His deep incisive eyes and his tall and imposing frame radiated warmth and compassion that could "discover" virtues in anyone he met. Above all, he was a teacher inside and out. Until the very end of his life, his quest for knowledge was unsa-tiated and he remained keenly interested and aware of the research activities of students, even those only remotely associated with him. He was indeed a builder of the finest institutions, and of the men and women whose commitments and competence go towards making buildings into institutions. Such builders are rare and much sought after in any society, but they are most invaluable for those emerging from the yoke of prolonged bondage. It was our fortune that he served the world of science through India, prepared us to appreciate the modern day revolution brought about by genetics and molecular biology, and trained us so that we could, in our small ways, be part of this revolution.

T. Sharma

Cytogenetics Laboratory,

Department of Zoology,

Banaras University, Varanasi, India

142

Cytogenet Cell Genet, Vol. 67, 1994 